\title{
Integration of National Character Education and Social Conflict Resolution through Traditional Culture: A Case Study in South Sumatra Indonesia
}

\author{
Alfitri $^{1} \&$ Hambali $^{2}$ \\ ${ }^{1}$ Faculty of Social and political Sciences, University of Sriwijaya, Indonesia \\ ${ }^{2}$ Faculty of Teacher Education, University of Riau, Indonesia \\ Correspondence: Alfitri, Faculty of Social and Political Sciences, University of Sriwijaya, Indonesia. E-mail: \\ al_fitri2002@yahoo.com
}

Received: August 1, 2013 Accepted: August 16, 2013 Online Published: August 30, 2013

doi:10.5539/ass.v9n12p125 URL: http://dx.doi.org/10.5539/ass.v9n12p125

\begin{abstract}
Local wisdom is related to the community's ability to understand the surrounding condition and the environment, which then is adapted to the existing situation. Local wisdom contributes to the way of living, knowledge and life strategies in the form of actions done by the local community to respond to various problems and meet their needs in life. Each community has its own outlook about a conflict that it is facing. The outlook is very dependent on the general conceptual framework, or a culture that surround it. Different outlook or perspective which causes differences can lead to a conflict between a community and another, which may trigger the myth of conflict. Every society has its own perspective of conflict, the myth of conflict, which differ from each other. "Tepung Tawar" (Fresh Flour) tradition is still still observed by people in Sumatra in resolving conflicts, marital ceremony, cleaning goods, either by individuals and groups, or between individuals and between groups. "Tepung Tawar" ceremony, called "tepungbedamai", is a specific ritual held to reconcile two parties in dispute, fighting or killing. "Tepung Tawar", a custom that is still developing and expanding in South Sumatra, is one of the local wisdom that is used as a tool of social control and for conflict resolution in the community. A society can model this cultural wisdom to achieve justice and unity by making sure that all parties reach an agreement and be willing to retain their anger and avoid a conflict.
\end{abstract}

Keywords: character education, conflict, "Tepung Tawar", traditional beliefs

\section{Introduction}

Local wisdom is related to the community's ability to understand the surrounding condition and the environment, which then is adapted to the existing situation Local wisdom contributes to the way of living, knowledge and life strategies in the form of actions done by the local community to respond to various problems and meet their needs in life. This term is also referred to as "local knowledge"or "local genious" (Rajab, 2006).

According to Wagiran (2012), the values of local wisdom are always inherent with the values of character education. In her study of "Pengembangan Karakter Berbasis Kearifan Lokal Hamemayu Hayuning Bawanapa damasyarakat Jawa" (Character Development Based on Local Wisdom HamemayuHayuningBawana on the Java community), philosophically, the local wisdom contains a comprehensive dimension of character. HamemayuHayuningBawana means to always strive to increase people's welfare and to encourage and cultivate such attitudes and behaviors of individuals that which emphasize the harmony of man with man, man with nature, and man with God in their lives. The findings reiterate that local wisdom is inherent in character education.

Local wisdom is revealed in the ability to adapt the knowledge in everyday life, and is usually manifested in the natural and social balance towards harmonization. The values of character education also exists in peusijuek which is done by the Acehnese society, to achieve peace between two disputing parties. In the Acehnese society, peusijuek (ditepungtawari) is a sacred and philosophical tradition. The Headmaster of the State Institute of Islamic Studies ArRaniry Banda Aceh, Rusjdi Ali Muhammad, said that, in Aceh, apart from the peusijuektradition, "peradilanadatlaut" (sea customary law) is still being practiced although is now hundreds of years old, and has existed since the period of the Sultanate of SamuderaPasai in the $14^{\text {th }}$ century - and thus even more believed to be a reliable conflict mediation. The verdict passed by "PeradilanAdatLaot" has proven to be 
authoritative and has never been objected by the disputing parties, said Rusjdi. According to Rusjdi, the authority of the law is held by its Commander. The authority has existed since the period of the Sultanate of IskandarMuda. The "PeradilanLaot", includes fishing procedures, distribution of the catch, and when fishermen should or should not go to sea. The judicial verdict has never been objected even once. This tradition in Aceh has proven and provided valuable lessons that besides the Penal Code, the customary law is actually something competent and able to bind people to comply with the law. Unfortunately at times, there are disputes in the society that has already been settled through custom law, which are taken to the realm of public justice by police and prosecutors.

South Sumatra (Sumsel) as an area that is rich in local wisdom among its people has demonstrated that every society has its own way in maintaining and achieving life balance. Sociologically, Sumsel community structure has flexibility in maintaining balance and control in the society. Balance and control is realized in the form of manifestations of tolerance and togetherness in everyday life which is a main pillar in the control of conflict towards achieving harmony. One of the local customs that has a value of local knowledge is "TepungTawar". The values internalized in the tradition of "tepungtawar" that gives harmony of life to the community, is a form of real opportunity for character development. This paper will specifically examine the tradition of "tepungtawar" in the process of conflict resolution in South Sumatran community.

\section{Literature Review}

\subsection{The Concept of Character Education}

Character education has increasingly been a topic of discussion among academicians and educational practitioners. The historical development of character education has begun since the Greeks and Romans time, through the philosophers, giving birth to the three phases of development or historical moment, namely 1) the reflection of human experience, 2) a reflective moment, with the interpretation and understanding of the experience, and 3) practical moment, namely the actualization of character education at the practical level (Muslich, 2011:37). The history clearly portrays the dynamics of character education development.

The essence and character education has the same meaning as morality and moral education. The objective is to form children's personalities to become good human beings, citizens, and good citizens. The criteria of good people, good citizens, and good citizens for a community or nation, in general is a certain social values, which are influenced by the culture of the community and nation. Therefore, the essence of character education in the context of education in Indonesia is the value of Education, the educational noble values sourced from Indonesia's own national culture, in order to nurture young personality (MONE, 2010:13).

Sumijati explains that the design of character education in schools should be through school model of harmony. The concept of school harmony, the values of harmony, peace, and peace in the learning activities should be undertaken by teachers, students, and all elements of the school. "Character education in schools teaches life harmony in diversity, building trust, mutual understanding and foster appreciation and openness in thinking. Sumijati affirms that cultural practice harmony in schools can be done by reflecting shared social violence that occurs among students to create a culture of harmony among students. Teaching about conflict resolution is necessary as a way to internalize the value of peace and harmony in the school community.

According to Thomas Lickona, in Gunawan (2012:23), character education helps shapes someone's personality which results in concrete actions. Apart from that, Elkind and Sweet as cited by Gunawan (2012) say that character education is an effort to understand others, and being concerned with the ethical values. According to Ramli as cited in Gunawan (2012), character education means moral education which aims to establish a child's personality to be a good man, a good memver of the society, and a good citizen. Based on some of these concepts, it can be concluded that character education is a process of forming a good personality, caring and responsive, through socialization and internalization.

The process of character education must be functional in the following ways: 1) 1) develop basic potential in order to be good-hearted, good-minded and well-behave. 2) strengthening and developing people's behavior in a multicultural society 3) increased competitive civilization in the social world (Gunawan, 2012). In order to achieve substantive goals of character education, members of the society need to be given enough opportunity for socialization and internalization for the values to be instilled through habituation (customizing), cognitive (ideas), and affective aspects (feelings and attitudes), and psychomotor aspects (regular movement). Based on sociological approach, character or personality is formed through a process of socialization, namely a process that involves the formation of attitude to behave in accordance with the behavior of the group (Soekanto, 2005:187). From the process, it can be seen that the transformation of character values largely determines the time when and the place where a person is socializing. Certainly there are many factors that influence the 
formation of one's character.

Lickona (1996) proposed to define character as Character so conceived has three interrelated parts: moral knowing, moral feeling and moral behavior." According to her, a noble character starts with having the knowledge of the good, which is then generated into commitment or intention to do good, and finally executing the good. Similar toLickona's view, Freud in Soedarsono (2000) refers to the sense of character as a set of values in the motivational system that forms the underlying thoughts, attitudes and behaviors which shape personal excellence through the combined values of the self and the values of social environment. This means that the character refers to the moral values that develop one's self-esteem and dignity. According to Kilpatrick (1992), the formation of national character can be done through a process of acquiring knowledge (knowing) to the customization of actions (habits), as knowledge is obtained and then is applied into action through training and continuous education to tell the difference between the good and the bad influence.

DoniKoesoerna (2007) considers character as personal values that lead to a person's traits and characteristics to be accepted and formed by three types of environment: home, school and community. Character Development Blueprint (Blue Print Pembangunan Karakter) (2010) is in agreement with Lickona's views that one's good behavior is derived from moral knowledge, moral values and good feelings toward moral behavior itself. In other words, it involves knowledge, intention and actions. Kalijernih (2010) refers to good behavior as efforts to invite people to revert to the original state of human creation as the best of creation that have the tendency towards goodness, maintaining dignity and upholding the values that are true and correct.

Megawangi (2004) propose the 4M formulafor the success of character education, in line with the concept of character highlighted by Lickona: know (mengetahui), feel (merasai), want (menginginkan) and do (melakukan). For the success of all forms of good moral action, Kerr (1999) has outlined five methods of character education that can be applied in educational institutions, namely: providing guidance, becoming a model, determining priorities, conditioning and doing reflection.

The true value of local wisdom is developed out of the understanding of man as a microcosm of macrocosm, expressing ideas, thoughts, conduct, customs and culture. Character education and development in the society never escapes the influence of cultural values. The process of character education which is based on the local values is internalized through informal socialization process that occurs in the community. The end result of character education at least produces six pillars of character: trustworthiness, fairness, caring, respect, citizenship and responsibility (Muslich, 2011:39). Similarly, the "tepungtawar" tradition was started from local wisdom and has the spirit of character education and development in the society

\subsection{Conflicts and Conflict Resolution}

Practitioners who focus on the study of conflict always rest a case with a clear rule, i.e. there is a clear regulations and a ground of rules. However, in connection with the guarantee of justice for all parties concerned, there is a win-win solution. This principle is different from the positive law, in which the wrong must be punished, namely, there is victory and defeat. In a win-win solution, each party benefits from the resolution. On the principles of democracy, which includes participatory, transparent, controlled and accountability, in Borneo for example, to prosecute the guilty, the court is so transparent that it is contrived in public. This includes the gender aspect, too. However, based on the rules, the case is clearer. Some cases in Kalimantan for example, when women are abused and the men demanded, the differing customs and legal rules, it is difficult to resolve the conflict. Thus, these customary rules should be transparent, develop humanism, and educate critical awareness.

For example, in old times "Hello girl" may not be a harassment, but now the girl can come forward and sue the person saying it. It is a concern whether the issue can be solved by custom.

Many experts have proposed the definitions of conflict. From various definitions and resources available, the term conflict can be summarized and interpreted as follows:

1) conflict is a natural form of conflict generated by individuals or groups because those involved have different attitudes, beliefs, values, and purposes;

2) a conflicting relationship between two or more parties (individuals or groups) who have or feel that they have specific goals, but inconsistent thoughts, feelings, or actions;

3) disagreement or dispute because there are different needs, values, and motivation of the perpetrators or those involved in it;

4) a process that occurs when one party is negatively affecting the other, including physical violence that makes 
others disturbed emotionally and physically;

5) the form of conflict that is functional because such conflict support the goals of the group and update the look, but is dysfunctional because it eliminates the appearance of existing ones;

6) the process of obtaining monopoly rewards, power, ownership, by removing or making the competitors vulnerable;

7) a form of resistance involving two parties antagonistically

8) chaos and contradiction within an individual.

The description above demonstrates that in every conflict there are several elements as follows: (a) There are two or more parties involved, (b) There is a purpose which is used as a goal of the conflict, and the goal is also the source of conflict. (c) There are different thoughts, feelings, and actions of the parties involved in getting or achieving goals; and (d) There is a conflict between the two conflicting parties.

The above definition also demonstrates that a conflict does not always mean violence or war. A lot of conflict, often referred to as latent conflict, actually still exist and have not come to the surface. We can conclude that a slightest difference in public opinion is a conflict, even if it has not so impacted negatively on the community. However, if we do not manage it properly, differences in opinion may turn into violent conflict.

Each community has its own perspective about the conflicts that occur in their environment. Their perspective is relies largely on the general conceptual framework, or the culture that surround them. Different perspective among different societies leads to different interpretations about conflict, which then raises the myths about the conflict. This myth then disillusions that every society has its own mythology or perspective of conflict, which would differ from one another.

There are a number of myths, among which are: first, a myth states that harmony is normal, and if there is a conflict, the situation is not normal. Some regard this myth as false as they assume that conflict is something natural, normal and inevitable so long as there are interactions between humans. Second, a myth states that a conflict happens because of differences in personality. For some people, this may be considered as false because there is a view that conflict occurs because of different attitude and perception among different people. Third, a myth states that conflict and contradiction are the same, while some people consider them as different because a contradiction is just a difference in opinion, while a conflict indicates threat. Contradiction is constrained by rationale, whereas conflict is accompanied by threats, anger, and is often done irrationally. Fourth, a myth states that a conflict is an unusual event that could bring damage to the society, but it can be solved. However, there is also a myth that says otherwise. Fifth, conflict is seen as a process for something that was going on, is non zero sum game, productive and manageable. Sixth, conflicts are natural and can not be avoided, and therefore, can be resolved or will resolve itself.

Many views and myths about conflict lead to difficulty of resolving conflicts in society as people have their own views about a conflict and it should be resolved, and different perspectives and solutions come with different repercussions.

\subsection{Causes of Conflicts}

To be able to resolve a conflict in the community, it is important to know its cause. With the knowledge about the cause, the conflict can be expected to be solved sooner. According to the conflict theory, society is always changing, and every change contributes to the occurrence of conflict in society. Based on this theory, a society is united through "an imposed lack of freedom". Thus, there are people in certain positions who delegate their power and authority to people in other positions. Dahrendorf focuses on this fact of social life in his thesis that the difference in distribution of power and authority "has always been a determining factor for a social conflict that is systematic". The differences in power distribution then brings into being two groups with different positions, i.e. the dominant group and the subordinate group. Those who are in a dominant position tends to maintain the status quo, while those who are in a subordinate position are always working to continually change and improve. Conflicts of interest in group is always there all the time, at least hidden. Somewhat different from the above conflict theorists, Collins, a sociologist, emphasizes that conflicts are rooted in individual problems as theoretical roots are rather phenomenological and ethnometodology. He defines conflict as focusing on a realistic basis; conflict is a central process in social life. Causes of conflict is found to be too complex to be understood and less directly lead to the realistic level of a conflict.

In general, there are some ways to resolve a conflict, namely (1) prevention of conflicts, which is intended to prevent violence in conflict, (2) conflict dismissal; aims to end violence through peace agreements, (3) conflict 
management; aims to limit or avoid violence or encourage change by the parties involved in order to behave positively; (4) Conflict resolution; aims at addressing the causes of conflict, and seek to develop new relationships that can last long between hostile groups, (5) Conflict Transformation; overcome source of social and political conflict, by diverting negative strength from the source of the difference to positive strength.

In addition to understanding the terms of the conflict resolution, it is also important to understand: (1) stages of the conflict, (2) stages of conflict resolution, and (3) three assumptions in conflict resolution. The stages of the conflict is the potential for opposition, or the driving situation, cognition and personalization, and ending -handling of conflict, a clear conflict behaviors, and outcomes. The stages of conflict resolution includes data collection, verification, hearing both sides of the conflict, creating the impression of the importance of cooperation, negotiation, and creating harmony.

In the meantime, the assumptions in conflict resolution are: (1) Lose-lose; everyone involved in the conflict will lose its claim if the conflict continues, (2) Lose-win; one of the parties is a loser, and only one party wins from the settlement of the conflict. If the losers cannot accept the solution fully, it is an indication that new conflicts may emerge; (3) Win-win: both parties in conflict win. This could happen if the two parties lost a little of its claim, but the end result may satisfy both. This term is more popular with the name of a win-win solution where both sides win and no one feels aggrieved.

Other than the above assumptions, knowledge of the strategies for conflict dismissal, i.e. ending a conflict is also necessary. There ar eat least ten strategies to dismiss or end a conflict, namely, avoiding, dominating, obliging, getting help, being humorous and relaxed, postponing, compromising, integrating, and problem solving and cooperating in solving the problem.

Meanwhile, there are many theoretical models to resolve a conflict. However, this article discusses several of them. First, the resolution model is based on the sources of conflict. In this model, the sources of conflict whether data of conflicts, relationships, values, structural, interests and so forth, must be known before the conflict is resolved. Once the source is known, the resolution process is started. Each source of the conflict has to be solved, and according to this model, there is no single way of conflict resolution. Second, Boulding's model offers a method to end a conflict in three ways: avoidance, conquest, and ending a conflict through reconciliation. Avoiding conflict offers time to choose possible solutions as the best answer. However, it should be noted that avoidance is a temporary solution to allow both parties to choose the best way to end the conflict.

Conquest means mobilizing all strength in applying resistance strategies to the conflict. Ending conflict through reconciliation or compromise procedure is generally the best method and most quickly to end a conflict. Third, the model of cultural pluralism can help to carry out conflict resolution. For example, an individual or group is invited to give a specific reaction against the influence of the social environment by adopting a new culture, which is referred to as cultural assimilation. Besides assimilation, accommodation can also help resolve conflicts. In the process of accommodation, both or all groups experiencing conflict must agree to accept cultural differences, and acceptance should be through common interests. Fourth, third party intervention model consists of coercion, arbitration, and mediation. Coercion is a model of conflict resolution by means of coercion, in which each party is forced to end the conflict. Arbitration is the resolution of conflict by taking third party to decide which problems occurred, and the results of a third party must be complied with by the respective parties. Meanwhile, third-party mediation means only serves to bridge the resolution of conflicts that occur in the community. All four of the above is just a few of the existing models of conflict resolution. There are still many other models of conflict resolution. However, one thing to remember, every conflict has different complexity, so it is not advisable to apply only a model to solve it. To find a way out of conflict, the intricacy and the complexity of a conflict should be understood seriously.

\subsection{Local Custom as a Tool for Conflict Resolution}

In addition to different theoretical models of conflict resolutions that were discussed above, it must be remembered that Indonesian nation is a great nation that has a diversity of cultures. Every culture has its individual local wisdom in addressing the problems faced life, including the wisdom in resolving the conflict. Wisdom like this is often referred to as local knowledge (local wisdom).

Various conflicts in Indonesia are followed by the emergence of different theories of conflict resolution as reference material from outside and within the state in various discussions, seminars and conflicts analysis. However, the application of the theories is not easy as it is also difficult to predict other variable factors. The ongoing conflict in the archipelago, both vertical conflicts or horizontal conflicts have caused disruption to the resilience of the nation and states as it tends to spread to other aspects of national life, which cause the weakening of sense of unity among the majority of Indonesian citizens. 
The diversity of the Indonesian nation and its territory which is in the form of islands must be accepted as an objective reality that might have potentials for conflict or sources of conflict such as separatist conflicts, struggle for natural resources, issue of race/ethnic, economic inequality, crime, unemployment, civil war, armed rebellion, politics, and so on.

There are also potential conflicts that can lead to national integration, namely the potential for conflict between tribes, religion, race, class, regional centers, civil-military, government agencies / states, non-Java-Java, public authorities-society, and others. In addition, there are also potential conflicts which are characterized by the implementation of regional autonomy, such as conflicts between local governments (adjacent to each other), conflicts between local people against the government forces, the conflict between local government and central government, and so on.

Generally, conflicts of identity in a society tend to be more complicated and last a long time and difficult to manage, while conflicts characterized by history are difficult to solve as it involves sentiments. In trying to cope with it all, there is no recipe which can immediately heal the situation as it always appear as a complicated interactions between differing strengths in addition to the different social conditions in the country.

Patterns of conflict resolution in a district may not apply in other areas. Therefore, to determine the solutions, the conflict needs to be observed and analyzed based on not only the theories of universal conflict, but also national or local paradigm so that objectivity remains in the condition, value, and the livelihood of our nation. Factors that need to be analyzed for conflict resolution include: actors, issues, causes, scope, efforts ever undertaken, the type of conflict, direction / potential, the nature of violence, the region, the phase and intensity, capacity and resources, the tools, the situation of both parties, and so on.

In resolving a conflict, it is more appropriate if a model used is adapted to local conditions and culture of the region. It is ideal when the settlement is fully initiated by the community who still adhere to local customs and aware of the importance of local culture in maintaining and ensuring the integrity of the community. Among the local wisdom that has been in existence, and is still preserved are dalihannatolu (Tapanuli), rumahbetang (Kalimantan Tengah), menyamabraya (Bali), saling Jot dansalingpelarangan (NTB), siroyoingsun, ingsunyosiro (JawaTimur), alon-alonasalkelakon(Jawa Tengah/DI Yogyakarta), danbasusunsirih (Melayu/Sumatra). Tradition and local wisdom that are still applied in the community have the potential to encourage the desire to live in harmony and peace as these principles basically teaches peace with each other, the environment, and God.

It is appropriate to resolve conflict using local knowledge as long as it is rooted in the society. Local knowledge is something that has taken root and is usually not just a mere profane-oriented, but is religious-oriented so that its implementation can be more quickly and easily accepted by the public. It is hoped that the local custom can bring about conflict resolution, and will be accepted by all parties so that there will be no more hidden conflict in the society.

Conflict does not always have negative consequences in a society. By managing it well, a conflict can actually benefit a society such as triggering changes in society, updating decision quality, innovation and creativity, as a means of evaluation, and so forth. Nevertheless, it is possible that if the conflict is not managed properly, it will have a negative impact and is detrimental to the society.

In order to solve a conflict, the intricacy and the complexity of a conflict should be understood seriously. It is important to realize that because of this, applying just a single theory to resolve a conflict may not be sufficient. It is necessary to remember that other than conflict resolution theories, the society also has its own customs in solving the problems of its people.

However, customs and the local culture are frequently forgotten in conflicts resolution process. For this reason it is important to explore the richness of the culture. One of the local cultural wisdom that is still growing and developing is a form of traditional ceremonies called TepungTawar which serves as a means of conflict resolution between the conflicting parties, and it is still effective enough to be used as an exemplary society. This model is a form of local wisdom or traditions that is potential to be developed as a means of conflict resolution in the midst of many conflicts that arise due to the lack of public confidence in the judiciary which is supposed to be an exemplary figure in resolving conflicts in the society.

\section{Research Purpose}

This study aims to determine the so-called traditional beliefs with "TepungTawar" in resolving conflicts that prevail in the society of South Sumatra. Also, the traditional belief in "tepungtawar" is also identified as a form of character education concept and being included in the implementation of curriculum in Indonesia today. 


\section{Research Methodology}

This paper investigates on character education in the traditional practice of TepungTawar in South Sumatera, using qualitative approach which describes a variable, symptom or condition and was not intended to test a particular hypothesis. It was considered that qualitative analysis would usefully allow for descriptions to fully understand the customs and traditions within the community by using methids such as in-depth interviews, focus group discussions, observation and document analysis. The instrument is used to get an in-depth, holistic and comprehensive qualitative data for the study of the subject.

The key informants in this study were the traditional leaders or figures in the community who have the knowledge of the traditional practice "tepungtawar", and were selected based on their roles in the community. In addition, individuals who were directly involved in "TepungTawar" were also used as study informants. Several groups in the community were also used as informants in this study through their participation in the FGD group. The informants are also selected based on the position in the community, age group (the older generation, and younger), and gender aspects. Variations of the informants allows the study to obtain comprehensive data, so that the meaning of the tradition and character education will gain in-depth results.

Both primary and secondary data are analyzed through three stages: first, data were collected from documents, in-depth interviews, and focus group discussions. The data are identified in accordance with the purposes of the study, a process often called data reduction. Second, data were presented to be easily understood. Data will be shown through the description, matrices, charts and tables; third, data are concluded from the interpretation which has been done earlier.

\section{Research Findings and Discussions}

\subsection{The Tradition of "TepungTawar" in South Sumatera}

The cultural practice of TepungTawar is still commonly used by the people of South Sumatra as a form of conflict resolution, marriage ceremonies, and clearance of goods, whether conducted individually, or in groups, inter-individual or among groups. In the traditional marriage ceremony, the practice of "TepungTawar" which is carried out after mandikasai, involves the wedding couple to be smeared with flour on half of their bodies as a symbol of harmony in their marriage. On the bride and groom's faces, flour is smeared on their faces as a sign of inviting harmony in their domestic life and implies that the radiant from their pure hearts must start from "Tampakan" (what is seen) from their faces so that they always have self-control and good behaviour in their new life.

Cleaning of goods or materials, usually when buying a car or a motorcycle, or a new house, is also performed with "TepungTawar". In this context, it can be interpreted that the flour sprinkled to the new object is a symbol of getting rid of the danger of accidents, either hitting others or being hit by others, and when carried out in a new home, the occupants will feel calm and free from interference of conflicts between family members or neighbors. So the function of this ritual is substantially is to ask for protection from the power to avoid from all kinds of distress which can be life-threatening or bring death. The sense of trust and demand for protection is reflected in the use of white rice flour pounded to powder and mixed with clear water and then mixed with the leaves which are derived from forest, to mean giving protection, healing, prudence, and as an antidote to spirits that are believed to interfere with harmony.

"TepungTawar" ceremony as an effort to solve a conflict between two disputing parties, is called the rite of "TepungTawarbedamai" and is specially convened to reconcile the two parties or groups who are fighting or involved with murder. The ceremony is led by a traditional leader who is the organizer, and serves as a third party, or the mediator who mediated the peace between both sides. Before the ceremony begins, both sides must agree about the penalties that is to be negotiated, for example the form of animals (chicken, goat, cow / buffalo), plants (coconut, rice, and leaves), and the amount of money as a symbol of the maintenance grant. Once this is agreed upon by both parties, the ceremony is started. This ceremony can be performed at a place agreed upon by both sides in dispute, whether at the victims' home, at the scene, or public places such as the village hall, mosque or place or prayers.

The ceremony of tepungtawarbedamai is started by the perpetrator who comes to the victim home to bring the material as a penalty that has been previously agreed during mediation to decide and be consent about the penalty. The presence of the perpetrator at the victim's home is mediated by the head of the customs and is greeted by the family members of the victims as a symbol of reunification of both families in dispute. The ceremony is performed by accepting the penalty material delivered and the flour is then finely ground, and stirred in a white bowl to make a liquid. The traditional leader then sprinkles the rice flour at the victim's home 
while reciting prayers. The materials to make the liquid, and the tools used to sprinkle it is shown in the table. 1 below.

Table1. Ingredients for "TepungTawar" ceremony

\begin{tabular}{cccc}
\hline Basic Ingredients & Meaning & Basic Tools & Meaning \\
\hline Finely ground rice & A good heart/conscience & Banyan leaf & Protection \\
Stirred with clear water & Union of clear (clean) hearts & Sedinginn leave & Cold (cured) heart \\
& & Setasih leaves & Caution \\
& & Threads of three colors & Antidote against spirits \\
\hline
\end{tabular}

Source: Interview with Public Figures from South Sumatra, 2013. (Wawancara Tokoh Masyarakat Sumsel, 2013)

Materials for the ceremony can be divided into two types: the basic materials of finely ground white rice and clear water, and application materials made of three leaves and three colors of yarn. The symbolic meaning of the basic materials is that signs of conflict can be mitigated and the heart is clean and clear like the clear water and clean white flour fused into a liquid. This material is then sprinkled at the body or objects with application tools made from Banyan leaves that symbolize protection, Sedingin leaves that symbolizes a meaningful remedy, and Setasih that symbolizes caution. The three types of leaves are then tied with three colors of yarn that is a symbol of reunification of two parties (families or people) in a dispute. The person acting as a mediator is believed to symbolize the expulsion of evil spirits that can trigger anger and pent up emotions as a cause of conflict.

The ceremony symbolizes the need of self-control between the two parties in the dispute through the mediation process by a person who is considered as a neutral party who has the authority in taking decisions fairly and wisely in the society. Self-control is symbolized by the perpetrator's agreement to provide a number of materials to the victims. This operation is the symbol of anger that is forgotten. The parties who mediate and both parties in the dispute then hope and pray to God to get His protection and to be kept away from conflict in the future, and all agree to live in harmony and to care as symbolized by the Setasih leaves.

This ceremony is also instrumental in enhancing the value of justice as the victims are to accept the perpetrator. In case if the victim's family member is killed, they can still be united through a process which need the perpetrator's child to be appointed as a "shared child" (anak bersama) to "replace" the dead child. This is the meaning of justice through this ceremony, and although this confession feels very heavy, the ceremony can be used as a way for both parties to believe in as a symbol of solidarity after a conflict between two families as the incident that has happened cannot be reversed.

\subsection{Character Education in the Practice of "Tepung Tawar"}

Character education is a process of socialization and internalization of ideal values in the society. The value of local wisdom in the traditional practice of "Tepung Tawar" is a platform for character education in conflict resolution process in South Sumatra province. In line Suwito's opinion as cited in Wagiran (2012) local wisdom includes (1) developing and educating people based on recognition of human existence since in mother's womb; (2) education should be based on truth and noble sense, away from thinking in a wrong way or with undue haste or emotionally; (3) education should develop the moral, spiritual and affective domains, and not merely cognitive and psychomotor domains; and (4) the synergy of culture, education and tourism should be developed synergistically in character education.

The following figure can explain the character education within the traditional practice of "Tepung Tawar": 


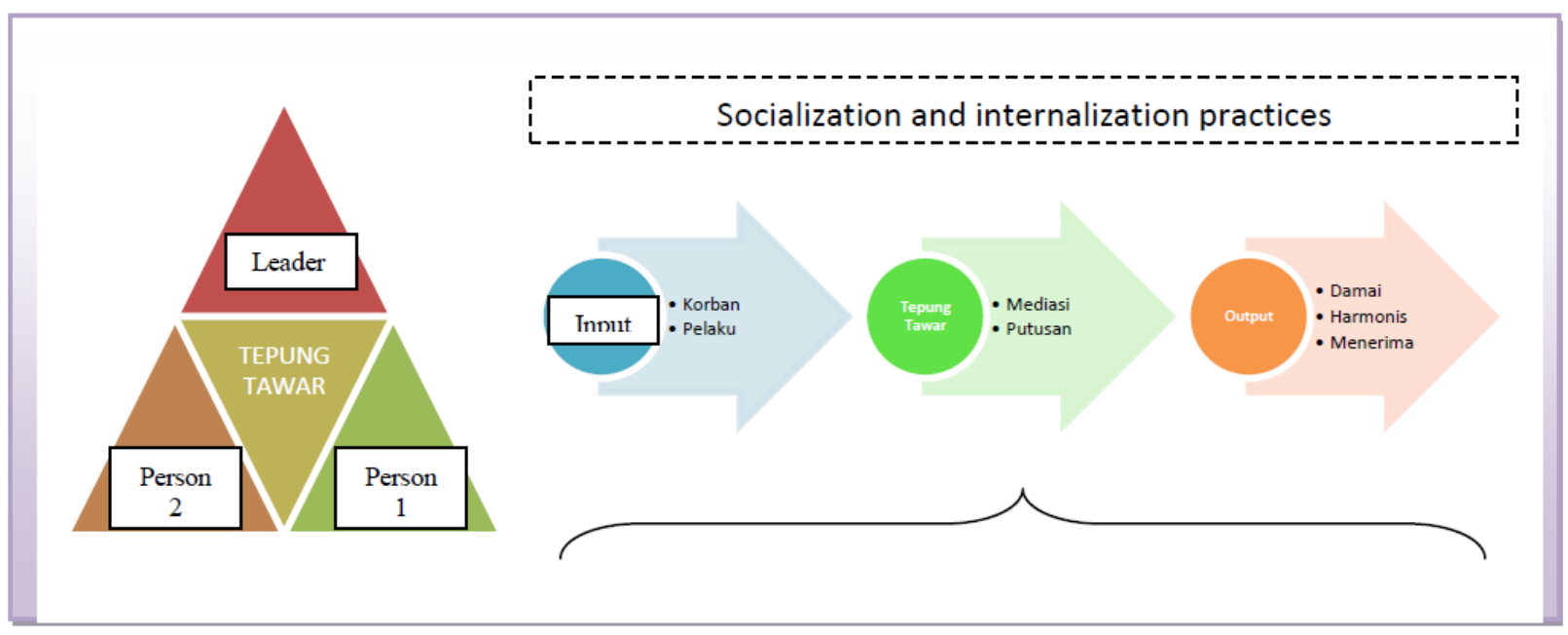

Figure 1. Conflict resolution process through "TepungTawar" and character education process

Source: Researchers’ Illustration (Ilustrasi Peneliti), 2013

Based on Figure 1, conflict resolution process with "tepungtawar" ceremony is a local mechanism that is similar to mediation, that is a conflict resolution method in modern times because of the emphasis on consensual solution. According to Ahmad Gunaryo, finding solutions together on a dispute through mediation led by a mediator in Indonesia is not a novelty. The use of local wisdom in conflict resolution, especially at the local level is very effective. This is because the values and rule have been internalization in the community. Thus, appreciation and acceptance of a decision last longer as socio-cultural aspect, a representation of the community, is the basis of the decision.

Character education is covered informally in the mechanism of conflict resolution through "tepungtawar".

Wisdom is contained in the symbolic gesture of "tepungtawar" tradition, which is characterized, perceived and interpreted by the wise and discerning people of Sumatra Selatan. This practice has created a peaceful life in the community. Character education values consist in the whole traditional process of "tepungtawar" if affixed with the theoretical framework of the six pillars of character. The traditional practice of "tepungtawar", analyzed comprehensively, contains the spirit of the six pillars of character as described in the following figure:

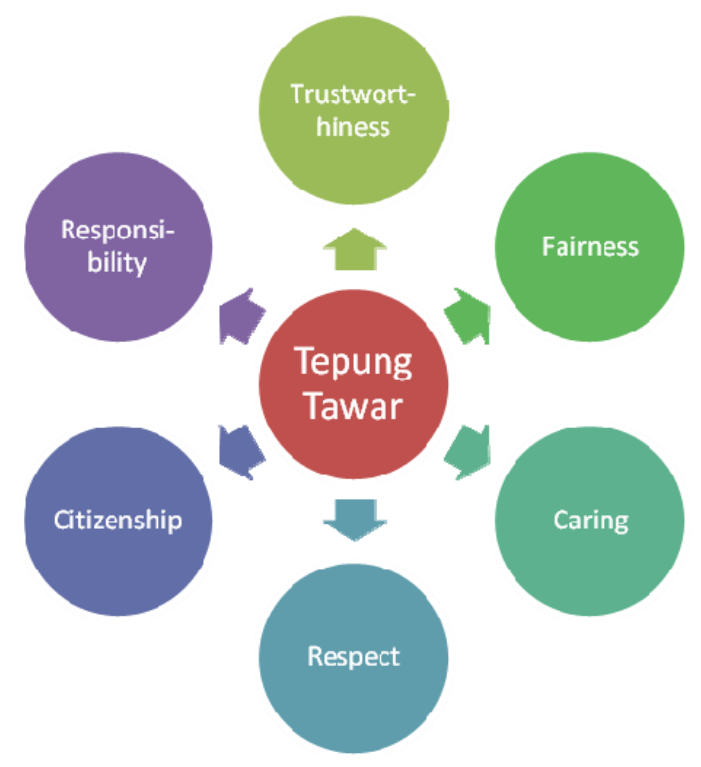

Figure 2. Six pillars of character scheme in "Tepung Tawar" traditions

Source: Researchers Reflections of Findings (Refleksi Temuan Peneliti), 2013 
As stated in the above figure, the traditional practice of "tepungtawar" has six pillars of character formation. The first pillar is trustworthiness; the mediation is done by a respected custom head that is knowledgeable, charismatic, able to sacrifice, honest, and loyal to the verdict, as the primary agent in the conflict resolution. The second pillar is fairness; all problems are solved with an open mind and without any pressure or not liking other people to benefit. The third pillar is caring; deliberation and consensus, the essence of the custom, produces a caring attitude and paying good attention to the problem of co-perpetrator or victim.

The fourth pillar is Respect; this traditional practice inculcates the semse of appreciation for the leader of the society, the mediator who informally conducts the session. The fifth pillar is citizenship; compliance to the leader who is appreciated as knowledgeable, just, and law-abiding. This condition is reflected by the harmonious community. The sixth pillar is responsibility; a fair verdict taken by the leader encourage other people to be responsible and disciplined in the community.

Thus, it can be concluded that "tepungtawar" is a local wisdom that has universal and human values. This sort of practice forms the real meaning of community, asserting that there is character education in the local wisdom.

\section{3 "Tepung Tawar": Strengthen Social Cohesion}

Every race, society and community culturally requires solid social conditions. The availability of social and community adhesiveness can help achieve harmony as required by all parties in life. According to Wicaksono and MulyaAmri (2008:18), there are several methods used to measure social adhesiveness in a society. They are: first, whether anyone is feeling isolated or being part of the community. This corresponds to the presence of values and common identity among community members. Second, whether there is equality (inclusion) or inequality (exclusion) of each community member, particularly in the case of opportunity and access of various resources, employment and social services / public. In this case the factors of economic justice, for example in the form of income distribution, which is an important factor to observe social adhesiveness. Third, whether there is involvement in various social activities or barriers and reluctance to engage; Fourth, if there is appreciation and reception (recognition) or no appreciation and no acceptance (rejection), which is particularly in the case of social differences, economic, tribal, and racial in the community. Fifth, if there is a feeling that the presence of an individual or group is valid (legitimate) or invalid (illegitimate), which is particularly relevant in the context of law against immigration / immigrants.

The traditional practice of "tepungtawar" strengthens social ties within a family, between families, local community and society. The most essential in the symbolic ceremony is the union of two families or a large family that can coexist in harmony. In the wedding ceremony, the symbol is the union of two different families, namely the host family and in-laws family, in a new household and is expected to be more binding and become one big family. In the ceremony of rejecting bad luck ("tolakbala") the ceremony is a means to ask for protection from the Most Powerful to be safe in using a vehicle or occupying a new home, as a symbolic gesture of being cautious in behavior. In "bedamai" ceremony, the traditional practice of "tepungtawar" is a symbol of the unification of the two parties in rival in a big family called bedulur, namely family who have blood ties and relatives as well as a new family reunification. This is a form of social cohesion that the warring families is united in a large family bonds by promoting the principle of self-control, respectively in an effort to keep the heart to be free of prejudice and slander to enable people to live in peace and harmony.

"Tepungtawar" ceremony contains a universal value which is used as a role model to maintain social cohesion, namely: the value of justice, as a fundamental value for harmony, which can be seen in the achievement of consensus in the conflicts mediated. The value of self-control is manifested from the symbols of clean and clear hearts, which is a source of peace in reducing emotional attitude, anger, even animalistic attitude which can go to the extent of killing others. Adhesiveness and togetherness is a moral value that is realized in the symbol of caution in attitude and opinion to avoid strife which can lead to conflict. The value of togetherness becomes binding on the parties in conflict in a larger families with the symbolic gesture of the splash of "tepungtawar".

\section{Implications and Suggestions}

The study found that the belief in "tepungtawar" can resolve conflicts in South Sumatran society. In addition, the practice can also be applied in shaping the character education. This study provides opportunities to many parties in the community for sustaining the use of "tepungtawar" in solving a problem or prevailing conflict. The cultural practice of "tepungtawar" shall continue to be developed and taught to the next generation to keep the nation's ancestral culture.

\section{Conclusion}

"Tepungtawar" is a traditional ceremony in South Sumatra used as a means to reconcile conflicting parties in 
order to unite the two families in a marriage, and to expect protection in using newly purchased materials such as car, motorcycle, or house. This tradition is still growing and developing and is conducted as conflict resolution. As one of the local culture, "tepungtawar" contains fundamental values that man should prioritize a pure and clear intention and spirit to avoid any conflict which always starts from a polluted heart or bad intentions. In addition, this practice is also a means of social cohesion in maintaining unity in a large family or neighborhood. This adhesiveness contains the value of togetherness in the life which is based on helping others and mutual cooperation as one of the social capital in the society. Moreover, this practice also contains six pillars of characters, namely, trustworthiness, fairness, caring, respect, citizenship and responsibility.

The practice of "tepungtawar" is still growing and developing in South Sumatra as a form of cultural wisdom which can be used as a means of conflict resolution and social cohesion in a society. Local knowledge can also be used as an example to the community that the values of justice and togetherness can be achieved if the parties are willing to reach an agreement and refrain from anger which can trigger a conflict. As a conflict resolution model, this traditional practice can be used as a reference and a comparative item in solving the problems faced by the nation.

\section{References}

Arikunto, S. (1999). Prosedur Kajian: SuatuPendekatanPraktek (Procedure of Investigation: A Practical Approach). PT. RenikaCipta: Jakarta.

Blue Print Pembangunan Karakter (Blue Print for Character Education). 2010. Departemen Pendidikandan Kebudayaan Nasional RI (Department of Education and National Culture, Republic of Indonesia).

Kerr. (1999). Developing a character education programme (Alexandria, Association for Supervision and Curriculum Development).

Kilpatrick, W. (1992). Why Johny can't tell right from wrong. New York: Simon \& Schuster. Inc.

Koesoerna, D. (2007). Pendidikan karakter (Character Education). Jakarta : Kompas Gramedia.

Lickona, T. (1996). Eleven principles of effective character education. Journal of Moral Education, 25(1). http://dx.doi.org/10.1080/0305724960250110

Lickona, T. (2004). Make you school a school of character. Retrieved from http://www.-cortland.edu/character

Liliweri, A. (2009). Prasangka \& Konflik, Komunikasi Lintas Budaya Masyarakat Multikultur (Prejudice and Conflict, Cross Cultural Communication in Multicultural Societies).Yogjakarta: LKis.

Megawangi. (2003). Pendidikan karakter untuk membangunmasyarakatmadani (Character education in building a civil society). IPPK Indonesia Heritage Foundation.

Muslich, M. (2011). Pendidikan Karakter Menjawab Tantangan Krisis Multidimensional (Character Education in Answering the Challenge of Multidimensional Crisis). Jakarta: PustakaAksara.

Rahmandi, T. (2010). Mediasi, Penyelesaian Sengketa Melalui Pendekatan Mufakat (Mediation, Resolution of Dispute Through Consensus Approach). Jakarta: Rajawali Pers.

Soekanto, S. (2005). Sosiologi Suatu Pengantar (An Introduction to Sociology). Jakarta: Rajawali Pers.

Soemarno Soedarsono, H. (2009). Karakter mengantar bangsa dari gelap menuju terang (Character Brings the Nation from the dark into the light). Jakarta: Kompas Gramedia.

Susan, N. (2009). Sosiologi Konflik \& Isu-isu Konflik Kontemporer (Sociology of Conflict \& Issues of Contemporary Conflicts). Jakarta: Kencana Prenada Media Group.

Thung Ju Lan, D. (2010). Klaim, Kontestase dan Konflik Identiti, Lokalitas vis a vis Nasionalitas (Claims, Contestation and Conflict Identiti, Locality vis a vis Nationalities). Jakarta: Institut Antropologi Indonesia (IAI).

Wagiran. (2012, February). Jurnal Pendidikan Karater (Journal of Character Education). Universitas Negeri Yogyakarta.

Wicaksono, \& Amri, M. (2008). CSR untuk Penguatan Kohesi Sosial (CSR for Strengthening Social Cohesion). Jakarta: Yayasan Indonesia Business Link.

\section{Copyrights}

Copyright for this article is retained by the author(s), with first publication rights granted to the journal.

This is an open-access article distributed under the terms and conditions of the Creative Commons Attribution license (http://creativecommons.org/licenses/by/3.0/). 